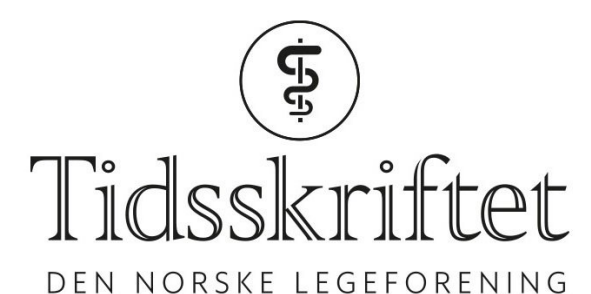

DEN NORSKE LEGEFORENING

\title{
Vitamin A, D og E og multippel sklerose
}

DOKTORAVHANDLINGER

EGIL RøRVIK RøSJØ

E-post: egilrr@gmail.com

Vitamin A, D og E kan virke antiinflammatorisk ved multippel sklerose, men redusert inflammasjon i årstider med høy D-vitaminproduksjon skyldes ikke kun økt D-vitaminnivå.

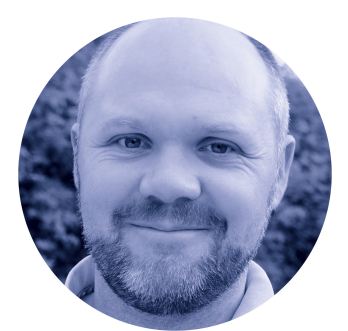

Egil Rørvik Røsjø. Foto:

Universitetet i Oslo

Multippel sklerose er en kronisk sentralnervøs autoimmun lidelse som rammer individer med en antatt genetisk sårbarhet og påvirkning av miljømessige risikofaktorer.

I mitt doktorgradsarbeid utforsket vi assosiasjoner mellom naturlige svingninger i nivået av vitamin $\mathrm{A}, \mathrm{D}$ og $\mathrm{E}$ og markører for systemisk inflammasjon, påvirkningen av D-

vitaminstatus på den antiinflammatoriske effekten av interferon- $\beta$-behandling, og effekten av høydose D-vitamintilskudd på den systemiske inflammasjonen hos pasienter med etablert attakkvis multippel sklerose.

Vi analyserte serumprøver fra 156 pasienter og MR-undersøkelser fra 88 pasienter som deltok i to norske, placebokontrollerte studier, hvor de primære målene var å undersøke effekten av henholdsvis omega-3- og vitamin D-tilskudd (20 ooo IU vitamin $\mathrm{D}_{3} /$ uke) på kliniske endepunkter. Resultatene viser at naturlige $ø$ kninger av vitamin A, D og E er assosiert med redusert inflammasjon, men effekten assosiert med en god D-vitaminstatus synes liten i forhold til, og påvirker ikke utbytte av, interferon- $\beta$-terapi. Videre har stigende D-vitaminnivå etter inntak av D-vitamintilskudd ingen tilsynelatende virkning på den systemiske inflammasjonen.

Våre funn antyder at det er gunstig å heve serumnivåene av vitamin A, D og E hos pasienter med attakkvis multippel sklerose og spesielt blant dem uten immunmodulerende behandling. Bruk av D-vitamintilskudd virker imidlertid ikke å gi den samme antiinflammatoriske effekten som økt soleksponering. 


\section{Disputas}

Egil Rørvik Røsjø disputerte for ph.d.-graden ved Universitet i Oslo 17. februar 2017. Tittelen på avhandlingen er Vitamin A, D and E and inflammation in multiple sclerosis.

Publisert: 4. september 2017. Tidsskr Nor Legeforen. DOI: 10.4045/tidsskr.17.0461

(C) Tidsskrift for Den norske legeforening 2020. Lastet ned fra tidsskriftet.no 